\author{
dr inż. Izabela Godyń \\ Politechnika Krakowska \\ Instytut Inżynierii i Gospodarki Wodnej \\ e-mail: izabela.godyn@iigw.pl
}

\title{
INSTRUMENTY EKONOMICZNE GOSPODARKI WODNEJ W ŚWIETLE PROJEKTU USTAWY PRAWO WODNE Z CZERWCA 2016 R.
}

\author{
ECONOMIC INSTRUMENTS OF WATER MANAGEMENT \\ IN THE LIGHT OF THE DRAFT WATER LAW OF JUNE 2016
}

\begin{abstract}
The paper presents the planned changes in the environmental fees system resulting from the Government's draft water law of 23 June 2016. The comparison of existing and proposed economic instruments is made based on the regulations of the draft law and the existing legislation. Analyses of charge rates for water services and the impact of their changes on prices of some products and services are conducted.
\end{abstract}

Keywords: ecological fees, water resources, water rights

JEL classification: H23, Q25, Q28

\section{Wstęp}

Istniejący system opłat ekologicznych opiera się głównie na przepisach ustawy z dnia 27 kwietnia 2001 r. Prawo ochrony środowiska (p.o.ś.), która w „Tytule V. Środki finansowo-prawne" reguluje opłaty za korzystanie ze środowiska oraz kary pieniężne.

Zgodnie z wymogiem art. 217 konstytucji, który mówi, że nakładanie danin publicznych następuje $\mathrm{w}$ drodze ustawy, w p.o.ś. zostały zdefiniowane m.in.:

- przedmiot opodatkowania, czyli rodzaje korzystania z wód objęte opłatami,

- stawki opłat,

- zasady przyznawania ulg i umorzeń - zwolnienia z opłat, a także możliwość uzależnienia wysokości opłaty np. od jakości wody i jej przeznaczenia, 
rodzaju substancji zawartych w ściekach, rodzaju i sposobu zagospodarowania terenu, z którego ścieki są odprowadzane $\mathrm{i}$ in.

Dodatkowe regulacje dotyczące opłat za korzystanie ze środowiska zawarto również w przepisach wykonawczych: rozporządzeniu, które określa jednostkowe stawki opłat (w ustawie są zawarte jedynie stawki maksymalne), a także współczynniki pozwalające na różnicowanie stawek w zależności m.in. od rodzaju ścieków, jakości i rodzaju pobranej wody oraz jej przeznaczenia, oraz obwieszczeniu, które corocznie aktualizuje stawki zawarte w ustawie i rozporządzeniu zgodnie ze zmianami cen obserwowanymi w gospodarce.

Procedowany od kwietnia 2016 r. rządowy projekt ustawy Prawo wodne (p.w.) przewiduje ,przeniesienie” zapisów dotyczących opłat za pobór wody oraz odprowadzanie ścieków z p.o.ś. do prawa wodnego. Odpowiednie artykuły w p.o.ś. zostaną uchylone, a wszystkie opłaty związane z korzystaniem z zasobów wodnych będą regulowane przez prawo wodne. Dodatkowo projekt p.w. poszerza zakres stosowania opłat za korzystanie z zasobów wodnych - dotychczas były to opłaty za pobór wód i odprowadzanie ścieków, teraz opłatami będą objęte ustugi wodne. Według art. 267-268 projektu p.w. opłaty za usługi wodne będą uiszczane za:

- pobór wód podziemnych lub powierzchniowych;

- wprowadzanie ścieków do wód lub do ziemi;

- odprowadzania do wód lub do ziemi:

- wód opadowych lub roztopowych, ujętych w otwarte lub zamknięte systemy kanalizacji deszczowej,

- wód pochodzących z odwodnienia gruntów na terenach miast, przemysłowych, obiektów lub wykopów budowlanych,

- wód pobranych i niewykorzystanych;

- zmniejszenie naturalnej retencji terenowej na skutek wykonywania robót i obiektów mających wpływ na zmniejszenie tej retencji;

- wydobywanie $\mathrm{z}$ wód powierzchniowych, w tym z morskich wód wewnętrznych wraz z wodami wewnętrznymi Zatoki Gdańskiej oraz wód morza terytorialnego, kamienia, żwiru, piasku oraz innych materiałów, a także wycinanie roślin z wód lub brzegu bądź z obszarów szczególnego zagrożenia powodzią.

Nowością będzie objęcie opłatami zmniejszenia naturalnej retencji oraz wydobywanie z wód powierzchniowych kamienia i innych materiałów. Natomiast odprowadzanie wód opadowych było dotychczas objęte opłatami, ponieważ wody opadowe były zaliczane do ścieków, a p.o.ś. przewidywało obowiązek uiszczania opłat za odprowadzanie ścieków - wód opadowych odprowadzanych z niektórych rodzajów powierzchni (zanieczyszczonych o trwałej nawierzchni, takich jak parkingi, drogi, lotniska $i$ in. ${ }^{32}$ ).

${ }^{32}$ Art. 3 pkt 38 lit. c ustawy z dn. 27 kwietnia 2001 r. Prawo ochrony środowiska (tj. Dz.U. z 2016 r., poz. 672 z późn. zm.). 
Poszerzenie zakresu stosowania opłat wynika także z rezygnacji ze stosowania zwolnień z opłat. Zwolnienia z opłat za pobór wody są wymienione w art. 294 p.o.ś. i obejmują pobór wody:

- dokonywany na potrzeby przerzutów wody;

- na potrzeby energetyki wodnej;

- powierzchniowej na potrzeby związane z wytwarzaniem energii cieplnej lub elektrycznej;

- na potrzeby funkcjonowania pomp cieplnych oraz geotermii;

- na potrzeby wykonywania odwiertów lub otworów strzałowych do badań sejsmicznych przy użyciu płuczki wodnej;

- na potrzeby chowu lub hodowli ryb oraz innych organizmów wodnych;

- na potrzeby nawadniania gruntów rodzinnych ogrodów działkowych;

- na potrzeby nawadniania wodami powierzchniowymi użytków rolnych i gruntów leśnych;

- pochodzącej z odwodnienia gruntów, obiektów lub wykopów budowlanych i zakładów górniczych.

Zgodnie z projektem p.w. ze zwolnień nie będzie już korzystać m.in.: energetyka konwencjonalna (wody do chłodzenia), energetyka wodna, rolnictwo (woda do nawodnień), hodowla ryb.

Poniżej, w kolejnych podrozdziałach, zostaną przedstawione dla wybranych rodzajów usług wodnych najistotniejsze planowane zmiany w konstrukcji opłat, w tym zmiany stawek opłat, oraz wprowadzenie opłat stałych i zmiennych. Pokazany zostanie również wpływ planowanych zmian na ceny końcowych produktów, np. wody wodociągowej oraz energii elektrycznej.

\section{Opłaty stałe}

Opłata za pobór wód, odprowadzanie ścieków oraz odprowadzanie wód będzie się składała z dwóch składowych: opłaty stałej oraz opłaty zmiennej. Opłata stała będzie naliczana w oparciu o pobór/zrzut maksymalny określony w zgodzie wodnoprawnej, a opłata zmienna w oparciu o rzeczywiste korzystanie z zasobów wodnych. Taka konstrukcja opłaty ma za zadanie ,urealnienie" i rewizję dotychczasowych pozwoleń wodnoprawnych. Według obowiązujących przepisów użytkownicy płacą jedynie za rzeczywiste korzystanie, które często jest dużo niższe niż pobór czy zrzut, o jaki występowali w pozwoleniach wodnoprawnych. To przykładowo powoduje, że użytkownicy posiadający obowiązujące pozwolenia wodnoprawne na pobór mają zapewnioną ,rezerwację" zasobów wodnych w zawyżonych wysokościach, co w zlewniach o znaczącym poziomie wykorzystania zasobów może spowodować, że teoretycznie może ich zabraknąć dla nowych 
użytkowników. Różnice w maksymalnych i rzeczywistych wielkościach poborów oczywiście zawsze będą występować, bo wynikają ze zmiennego w czasie zapotrzebowania, jednakże bodziec ekonomiczny w postaci opłaty stałej zależnej od poboru maksymalnego z pewnością spowoduje, że duża część pozwoleń wodnoprawnych zostanie zweryfikowanych.

\section{Optata stata za pobór wód}

Stawki opłaty stałej są zależą od ilości pobranej wody oraz rodzaju wody (powierzchniowa/podziemna), wielkości zasobów definiowanych przez średni niski przepływ SNQ w przypadku wód powierzchniowych oraz udokumentowanych zasobów wód podziemnych. Jednostkowe stawki opłaty stałej wynoszą (art. 282 ust. 1 pkt 1 projektu p.w.):

1) za pobór wód podziemnych:

- 500 zł na dobę za $1 \mathrm{~m}^{3} / \mathrm{s}$ za określony w pozwoleniu wodnoprawnym albo zintegrowanym maksymalny pobór wody, jeżeli pobór wody jest mniejszy niż 10\% dostępnych zasobów wód podziemnych;

- $1000 \mathrm{zł}$ na dobę za $1 \mathrm{~m}^{3} / \mathrm{s}$, jeżeli pobór wody jest większy niż $10 \%$ i mniejszy niż 30\% dostępnych zasobów wód podziemnych;

- 2000 zł na dobę za $1 \mathrm{~m}^{3} / \mathrm{s}$, jeżeli pobór wody jest większy niż $30 \%$ dostępnych zasobów wód podziemnych;

2) za pobór wód powierzchniowych:

- $250 \mathrm{zł}$ na dobę za $1 \mathrm{~m}^{3} / \mathrm{s}$ za określony w pozwoleniu wodnoprawnym albo zintegrowanym maksymalny pobór wody, jeżeli pobór wody jest mniejszy niż 10\% SNQ;

- 500 zł na dobę za $1 \mathrm{~m}^{3} / \mathrm{s}$, jeżeli pobór wody jest większy niż 10\% SNQ i mniejszy niż 50\% SNQ;

- $1000 \mathrm{zł}$ na dobę za $1 \mathrm{~m}^{3} / \mathrm{s}$, jeżeli pobór wody jest większy niż $50 \%$ SNQ.

Opłaty stałej nie będzie się jedynie ponosić za pobór wód przez elektrownie wodne oraz na potrzeby chowu i hodowli ryb.

Wysokość opłaty stałej dla przedsiębiorstw wodociągowych może być znacząca, przykładowo: krakowskie przedsiębiorstwo wodociągowe MPWIK posiada obecnie pozwolenie wodnoprawne na pobór wody ze zbiornika dobczyckiego na Rabie w wysokości $2,5 \mathrm{~m}^{3} / \mathrm{s}$, przy przepływie średnim niskim w przekroju Dobczyce (poniżej zapory) z lat 1991-2010 wynoszącym $2,485 \mathrm{~m}^{3} / \mathrm{s}^{33}$; opłata stała za cały rok będzie wynosić:

${ }^{33}$ Rozporządzenie Nr 4/2014 Dyrektora Regionalnego Zarządu Gospodarki Wodnej w Krakowie z dnia 16 stycznia 2014 r. w sprawie warunków korzystania z wód regionu wodnego Górnej 


$$
\text { Opłata st. }=2,5 \frac{\mathrm{m}^{3}}{\mathrm{~s}} \cdot 1000 \frac{\mathrm{zł}}{\frac{\mathrm{m}^{3}}{\mathrm{~s}} \cdot \mathrm{doba}} \cdot 1 \text { rok }=912,5 \text { tys. zł }
$$

Oczywiście w przypadku przekroju zaporowego trudno w sposób bezdyskusyjny określić SNQ, przytoczony powyżej przepływ w przekroju Dobczyce jest przepływem będącym wynikiem sterowania zbiornikiem, stąd prawdopodobnie stawka stosowana dla tego poboru będzie niższa 500 lub nawet 250 zł na dobę za $1 \mathrm{~m}^{3} / \mathrm{s}$. Jednakże nawet $\mathrm{w}$ takim przypadku opłata będzie miała znaczącą wysokość - odpowiednio 456 lub 228 tys. zł.

Rzeczywisty pobór ze zbiornika jest o wiele niższy niż maksymalny ujęty w pozwoleniu wodnoprawnym, weryfikacja pozwolenia do $2 \mathrm{~m}^{3} / \mathrm{s}$ może obniżyć opłatę stałą do 730 tys. zł (lub odpowiednio 365 i 182,5 tys. zł przy niższych stawkach 500 i 250 zł na dobę za $1 \mathrm{~m}^{3} / \mathrm{s}$ ).

\section{Oplata stała za wprowadzanie ścieków}

Stawka opłaty stałej za wprowadzanie ścieków do wód lub do ziemi wyniesie $500 \mathrm{zł}$ na dobę za $1 \mathrm{~m}^{3} / \mathrm{s}$ za udzielony w pozwoleniu wodnoprawnym albo w pozwoleniu zintegrowanym maksymalny zrzut ścieków. Przykładowa kalkulacja opłaty stałej dla MPWIK w Krakowie: łączna maksymalna wydajność oczyszczalni ścieków Kujawy i Płaszów ${ }^{34}$ wynosi 408 tys. m³/d, zakładając, że maksymalny zrzut jest bliski tej wielkości, to $\mathrm{w}$ przeliczeniu na $\mathrm{m}^{3} / \mathrm{s}$ powinien być na poziomie ok. $4,5 \mathrm{~m}^{3} / \mathrm{s}$. Opłata stała zatem wyniesie:

$$
\text { Opłata st. }=4,5 \frac{\mathrm{m}^{3}}{\mathrm{~s}} \cdot 500 \frac{\mathrm{zł}}{\frac{\mathrm{m}^{3}}{\mathrm{~s}} \cdot d o b a} \cdot 1 \mathrm{rok}=821 \mathrm{tys} . \mathrm{zł}
$$

Nowe stałe opłaty łącznie za pobór wód i zrzut ścieków dla MPWIK będą na poziomie ok. 0,5\% ogółu dotychczasowych kosztów (357 208 tys. zł według danych z $\left.2015 \mathrm{r}^{35}\right)$.

\footnotetext{
Wisły. Załącznik nr 5. Wykaz czynnych posterunków wodowskazowych wraz z ich charakterystyką hydrologiczną, s. 1.

${ }^{34}$ Według informacji na stronie MPWIK SA w Krakowie: http://wodociagi.krakow.pl/o-firmie/ infrastruktura.html (dostęp: 1.06.2016).

${ }^{35}$ Rachunek zysków $i$ strat za rok 2015, http://bip.mpwik.krakow.pl/katalog/strona, $15 . h t m l$ (dostęp: 1.06.2016).
} 


\section{Opłata stała za wprowadzanie wód opadowych i roztopowych}

Opłaty stałe będą również pobierane za odprowadzanie do wód lub do ziemi wód opadowych lub roztopowych ujętych w systemy kanalizacji otwartej lub zamkniętej dla obszarów o gęstości zaludnienia powyżej 1000 mieszkańców/km². Stawka opłaty będzie wynosić:

- za wprowadzenie do ziemi: 500 zł na dobę za $1 \mathrm{~m}^{3} / \mathrm{s}$ za udzielony w pozwoleniu wodnoprawnym albo zintegrowanym maksymalny zrzut wód,

- za wprowadzenie do wód: $250 \mathrm{zł}$ na dobę za $1 \mathrm{~m}^{3} / \mathrm{s}$.

Przykładowa kalkulacja opłaty stałej dla terenu osiedla mieszkaniowego o powierzchni 20 ha (m.in. parkingi, drogi, liczba mieszkańców 2800). Maksymalny zrzut wód opadowych do wód został określony w pozwoleniu w wysokości 500 1/s. Opłata stała wyniesie:

$$
\text { Opłata st. }=0,5 \frac{\mathrm{m}^{3}}{\mathrm{~s}} \cdot 250 \frac{\mathrm{zł}}{\frac{\mathrm{m}^{3}}{\mathrm{~s}} \cdot \mathrm{doba}} \cdot 1 \mathrm{rok}=46 \text { tys. } \mathrm{zł}
$$

\section{Opłaty zmienne za usługi wodne}

Opłata stała jest znaczącą składową opłaty za usługę wodną, ale podstawową jej część będzie stanowiła opłata zmienna, zależna głównie od rzeczywistego poziomu użytkowania. Stawki zmiennej opłaty za pobór wód zostały znacząco podniesione w stosunku do obowiązujących obecnie, także opłaty za odprowadzanie wód opadowych będą znacząco wyższe, jedynie stawki za odprowadzanie ścieków zawarte w projekcie p.w. nie ulegną zmianie i będą na poziomie obecnie obowiązujących.

W tabeli 1 zestawiono wybrane stawki opłaty zmiennej za usługi wodne. Projekt ustawy jest na etapie uzgodnień, stawki mogą więc jeszcze ulec zmianie. Te przedstawione $\mathrm{w}$ tabeli są podane zgodnie z projektem z dnia 23 czerwca 2016 r., który jest drugą już wersją projektu rządowego (pierwszy projekt ukazał się dwa miesiące wcześniej, 26 kwietnia) ${ }^{36}$. Stawki opłat w drugiej wersji projektu zostały znacząco obniżone dla wielu rodzajów usług wodnych, np. stawki za pobór dla niektórych celów trzykrotnie, a stawki za odprowadzanie zanieczyszczeń w ściekach i wód chłodniczych zostały obniżone do obecnie obowiązujących.

${ }^{36}$ Obydwie wersje projektu rządowego ustawy Prawo wodne są dostępne na stronie Rządowego Centrum Legislacji: http://legislacja.rcl.gov.pl/projekt/12284651/katalog/12349263 (dostęp: 1.06.2016). 
Tabela 1. Istniejące i planowane (wybrane) stawki opłaty zmiennej za usługi wodne

\begin{tabular}{|c|c|c|}
\hline $\begin{array}{l}\text { Rodzaj usług } \\
\text { wodnych }\end{array}$ & Istniejące stawki w 2016 r. & Planowane stawki w 2017 r. \\
\hline 1 & 2 & 3 \\
\hline $\begin{array}{l}\text { pobór dla celów } \\
\text { zaopatrzenia lud- } \\
\text { ności w wodę }\end{array}$ & $\begin{array}{l}0,068 \text { zł za } 1 \mathrm{~m}^{3} \text { wody } \\
\text { podziemnej } \\
0,040 \mathrm{zł} \text { za } 1 \mathrm{~m}^{3} \text { wody } \\
\text { powierzchniowej }\end{array}$ & $\begin{array}{l}\text { od } 0,60 \text { zł za } 1 \mathrm{~m}^{3} \text { pobranej wody w ilości prze- } \\
\text { kraczającej } 0,25 \mathrm{~m}^{3} / \mathrm{s} \text {, } \\
\ldots \\
\text { do } 0,15 \text { zł za } 1 \mathrm{~m}^{3} \text { pobranej wody w ilości nie- } \\
\text { przekraczającej } 0,001 \mathrm{~m}^{3} / \mathrm{s}\end{array}$ \\
\hline $\begin{array}{l}\text { pobór wody, która } \\
\text { wchodzi w skład } \\
\text { albo w bezpo- } \\
\text { średni kontakt } \\
\text { z produktami } \\
\text { żywnościowymi, } \\
\text { farmaceutycz- } \\
\text { nymi lub na cele } \\
\text { konfekcjono- } \\
\text { wania }\end{array}$ & $\begin{array}{l}0,097 \text { zł za } 1 \mathrm{~m}^{3} \text { wody } \\
\text { podziemnej } \\
0,057 \text { zł za } 1 \mathrm{~m}^{3} \text { wody } \\
\text { powierzchniowej }\end{array}$ & $\begin{array}{l}\text { produkcja artykułów spożywczych: } \\
0,70 \text { zł za } 1 \mathrm{~m}^{3} \text { wody podziemnej } \\
0,35 \text { zł za } 1 \mathrm{~m}^{3} \text { wody powierzchniowej } \\
\text { produkcja produktów farmaceutycznych: } \\
\text { 2,10 zł za } 1 \mathrm{~m}^{3} \text { wody podziemnej } \\
\text { 1,05 zł za } 1 \mathrm{~m}^{3} \text { wody powierzchniowej } \\
\text { produkcja napojów: } \\
8,20 \text { zł za } 1 \mathrm{~m}^{3} \text { wody podziemnej } \\
4,10 \text { zł za } 1 \mathrm{~m}^{3} \text { wody powierzchniowej }\end{array}$ \\
\hline $\begin{array}{l}\text { pobór wody } \\
\text { do celów prze- } \\
\text { mysłu }\end{array}$ & $\begin{array}{l}0,115 \text { zł za } 1 \mathrm{~m}^{3} \text { wody } \\
\text { podziemnej } \\
0,057 \text { zł za } 1 \mathrm{~m}^{3} \text { wody } \\
\text { powierzchniowej }\end{array}$ & $\begin{array}{l}0,70 \mathrm{zł} \text { za } 1 \mathrm{~m}^{3} \text { wody podziemnej } \\
0,35 \mathrm{zł} \text { za } 1 \mathrm{~m}^{3} \text { wody powierzchniowej } \\
\text { (uwaga - są także wyższe stawki dla niektórych } \\
\text { rodzajów przemysłu art. } 282 \text { ust. } 1 \text { pkt } 2 \text { ) }\end{array}$ \\
\hline $\begin{array}{l}\text { pobór wody } \\
\text { do nawadniania } \\
\text { wodami po- } \\
\text { wierzchniowymi } \\
\text { użytków rolnych }\end{array}$ & zwolniony z opłat & $\begin{array}{l}0,30 \mathrm{zł} 1 \mathrm{~m}^{3} \text { wody podziemnej } \\
0,15 \mathrm{zł} \mathrm{za} 1 \mathrm{~m}^{3} \text { wody powierzchniowej }\end{array}$ \\
\hline $\begin{array}{l}\text { pobór wody } \\
\text { do chłodzenia }\end{array}$ & zwolniony z opłat & $\begin{array}{l}0,70 \mathrm{zł} \text { za } 1 \mathrm{~m}^{3} \text { bezzwrotnie pobranej wody } \\
\text { podziemnej oraz } 0,164 \mathrm{zł} \text { za } 1 \mathrm{~m}^{3} \text { wody pobranej } \\
\text { zwrotnie } \\
0,35 \mathrm{zł} \mathrm{z} 1 \mathrm{~m}^{3} \text { bezzwrotnie pobranej wody po- } \\
\text { wierzchniowej oraz } 0,082 \text { zł za } 1 \mathrm{~m}^{3} \text { wody pobra- } \\
\text { nej zwrotnie, }\end{array}$ \\
\hline $\begin{array}{l}\text { pobór wody } \\
\text { przez elektrownie } \\
\text { wodne }\end{array}$ & zwolniony z opłat & $\begin{array}{l}1,24 \text { zł za } 1 \text { MWh wyprodukowanej energii elek- } \\
\text { trycznej w obiekcie energetyki wodnej za zwrot- } \\
\text { ny pobór wody oraz } 1,05 \text { zł za pobór } 1 \mathrm{~m}^{3} \text { wody } \\
\text { technologicznej nieprzeznaczonej wprost do pro- } \\
\text { dukcji energii elektrycznej }\end{array}$ \\
\hline
\end{tabular}


Tab. 1 (cd.)

\begin{tabular}{|c|c|c|}
\hline 1 & 2 & 3 \\
\hline $\begin{array}{l}\text { odprowadzanie } \\
\text { wód opadowych }\end{array}$ & $\begin{array}{l}\text { opłata za powierzchnie } \\
\text { zanieczyszczone o trwałej } \\
\text { nawierzchni, z których } \\
\text { są wprowadzane do wód } \\
\text { lub do ziemi wody opado- } \\
\text { we lub roztopowe, ujęte } \\
\text { w otwarte lub zamknięte } \\
\text { systemy kanalizacyjne, } \\
\text { z wyjatkiem kanalizacji } \\
\text { ogólnospławnej: } \\
\text { - } 0,29 \text { zł na } 1 \text { rok za } 1 \mathrm{~m}^{2} \\
\text { pow. terenów przemysło- } \\
\text { wych, składowy lub baz } \\
\text { transportowych, } \\
\text { - 0,070 zł na } 1 \text { rok za } 1 \mathrm{~m}^{2} \\
\text { pow. portów śródlądo- } \\
\text { wych, portów morskich } \\
\text { i lotnisk, } \\
\text { - } 0,057 \text { zł na } 1 \text { rok za } 1 \mathrm{~m}^{2} \\
\text { pow. dróg i parkingów } \\
\text { o nawierzchni szczelnej, } \\
\text { • } 0,086 \text { zł na } 1 \text { rok za } 1 \mathrm{~m}^{2} \\
\text { pow. parkingów o na- } \\
\text { wierzchni nieszczelnej, } \\
\text { o liczbie miejsc parkingo- } \\
\text { wych powyżej } 500 \text { samo- } \\
\text { chodów, } \\
\text { • } 0,041 \text { zł na } 1 \text { rok za } 1 \mathrm{~m}^{2} \\
\text { pow. dróg i parkingów } \\
\text { o nawierzchni szczelnej } \\
\text { położonych w miastach } \\
\text { o gęstości zaludnienia > } \\
1300 \text { osób/km² }\end{array}$ & $\begin{array}{l}\text { wody opadowe lub roztopowe ujęte w systemy } \\
\text { kanalizacji otwartej lub zamkniętej dla terenów } \\
\text { o gęstości zaludnienia powyżej } 1000 \text { osób/km²: } \\
\text { • bez urządzeń do retencjonowania wody z tere- } \\
\text { nów uszczelnionych - } 1,50 \text { zł za } 1 \mathrm{~m}^{3} \text { na } 1 \text { rok, } \\
\text { • z urządzeniami do retencjonowania wody } \\
\text { o pojemności powyżej } 10 \% \text { odpływu rocznego } \\
\text { z terenów uszczelnionych - } 1,00 \text { zł za } 1 \mathrm{~m}^{3} \\
\text { na } 1 \text { rok, } \\
\text { - z urządzeniami do retencjonowania wody o poj. } \\
\text { powyżej } 20 \% \text { odpływu rocznego - } 0,75 \text { zł } \\
\text { za } 1 \mathrm{~m}^{3} \text { na } 1 \text { rok, } \\
\text { - z urządzeniami do retencjonowania wody o poj. } \\
\text { powyżej } 30 \% \text { odpływu rocznego - } 0,15 \mathrm{zł} \\
\text { za } 1 \mathrm{~m}^{3} \text { na } 1 \text { rok }\end{array}$ \\
\hline $\begin{array}{l}\text { utrata naturalnej } \\
\text { retencji }\end{array}$ & brak opłat & $\begin{array}{l}\text { za utratę naturalnej retencji na obszarach nieuję- } \\
\text { tych w systemy kanalizacji otwartej lub zamknię- } \\
\text { tej o powierzchni powyżej } 1000 \mathrm{~m}^{2} \text { : } \\
\text { bez urządzeń do retencjonowania wody z obsza- } \\
\text { rów uszczelnionych - } 0,60 \text { zł za } 1 \mathrm{~m}^{2} \text { na } 1 \text { rok, } \\
\text { z urządzeniami do retencjonowania wody o poj. } \\
\text { powyżej } 30 \% \text { odpływu rocznego z obszarów } \\
\text { uszczelnionych }-0,10 \text { zł za } 1 \mathrm{~m}^{2} \text { na } 1 \text { rok }\end{array}$ \\
\hline
\end{tabular}

Źródło: opracowanie własne na podstawie Rozporządzenia Rady Ministrów z dn. 12 października 2015 r. w sprawie optat za korzystanie ze środowiska (Dz.U. z 2015 r., poz. 1875) oraz projektu ustawy Prawo wodne z 23 czerwca $2016 r$. 


\section{Opłaty za pobór wód dla celów zaopatrzenia i ich wpływ na cenę wody}

W celu oszacowania wpływu proponowanych zmian na cenę wody dla odbiorców dokonano przykładowej kalkulacji opłaty dla MPWIK w Krakowie za pobór wód według obowiązujących oraz proponowanych stawek, przy założeniu, że całość poboru jest realizowana z ujęcia na zbiorniku dobczyckim ${ }^{37}$. Przyjęto następujące dane wejściowe:

roczna sprzedaż wody $\left(2014 \mathrm{r}\right.$.) $=47200$ tys. $\mathrm{m}^{3}$

szacunkowo roczny pobór wody $\approx 120 \% \cdot 47200$ tys. $\mathrm{m}^{3}=56640$ tys. $\mathrm{m}^{3}$ stawka $2015 \mathrm{r}$. $=0,040 \mathrm{zł}$ za $1 \mathrm{~m}^{3}$ wody powierzchniowej

Opłata $_{2015}=56640$ tys. $\mathrm{m}^{3} \cdot 0,040 \frac{\mathrm{zł}}{\mathrm{m}^{3}}=2266$ tys. zł

Według projektu ustawy opłata będzie wynosić:

max pobór wg zgody wodnoprawnej $=2,5 \frac{\mathrm{m}^{3}}{\mathrm{~s}}$

stawka opłaty stałej $=500 \mathrm{zł}$ na dobę za $1 \mathrm{~m}^{3} / \mathrm{s}$ wody powierzchniowej, stawka opłaty zmiennej $=0,60 \mathrm{zł} \mathrm{za} 1 \mathrm{~m}^{3}$ wody powierzchniowej,

Opłata stała $=2,5 \frac{\mathrm{m}^{3}}{\mathrm{~s}} \cdot 500 \frac{\mathrm{zł}}{\frac{\mathrm{m}^{3}}{\mathrm{~s}} \cdot \mathrm{doba}} \cdot 1 \mathrm{rok}=456$ tys. zł

Opłata zmienna $=56640$ tys. $\mathrm{m}^{3} \cdot 0,60 \frac{\mathrm{zł}}{\mathrm{m}^{3}}=33984$ tys. zł

Opłata stała + zmienna $=34440$ tys. zł

Łączna opłata jest ponad piętnastokrotnie wyższa niż ta obliczona według obowiązujących stawek, co jest oczywiście kolosalnym wzrostem kosztów z punktu widzenia funkcjonowania przedsiębiorstwa. Dotychczasowa opłata była na poziomie ok. 0,4\% ogółu kosztów (według danych z $2015 \mathrm{r}^{38}$ ), nowa opłata stanowi ok. 9\% kosztów (kosztów dotychczasowych powiększonych o symulowany przyrost opłaty). Jednakże gdyby MPWIK ,przeniosło” ten wzrost kosztów na klientów, to podwyżka ceny wody nie jest tak wysoka. Oszacowanie przeprowadzono przy następujących założeniach:

podstawowa cena wody (netto) $=3,62 \mathrm{z} / \mathrm{m}^{3}$

roczne przychody $=431095$ tys. $z 1$

roczne koszty $=357208$ tys. zł

zysk netto $=67283$ tys. $z 1$

rentowność sprzedaży $=15,6 \%$

${ }^{37}$ W rzeczywistości ujęcie na Rabie zaspokaja ok. 60\% zapotrzebowania, pozostały pobór jest realizowany na ujęciach wód na Rudawie, Sance, Dłubni oraz ze studni głębinowych Mistrzejowice, http://wodociagi.krakow.pl/o-firmie/infrastruktura.html (dostęp: 1.06.2016).

${ }^{38}$ Rachunek zysków i strat... 
Jeżeli przedsiębiorstwo chciałoby utrzymać rentowność sprzedaży na poziomie $15 \%$, to cena powinna wzrosnąć o ok. $16 \%$ - do 4,19 zl $/ \mathbf{m}^{3}$.

\section{Oplaty za pobór wód dla celów produkcji napojów}

Branża produkcji napojów i wód jest jedną z branż objętych bardzo wysoką podwyżką stawek, stawka opłaty zmiennej za pobór wód podziemnych wzrasta z 0,097 do 8,20 zł/m³. Przeliczając nową opłatę na 11 wody, otrzymujemy zaledwie 8,2 gr, dodając jeszcze opłatę stałą średni wzrost ceny wody źródlanej butelkowanej nie powinien przekroczyć 10 gr na litrze.

\section{Opłaty za pobór wód w sektorze energetyki konwencjonalnej i wodnej}

Kolejnym sektorem gospodarki, który w sposób znaczący może odczuć zmiany w opłatach za pobór wody, jest energetyka. Pobór wody powierzchniowej na potrzeby związane z wytwarzaniem energii cieplnej lub elektrycznej był do tej pory zwolniony z opłat, według projektu p.w. stawka opłaty zmiennej dla potrzeb chłodzenia będzie wynosić - dla instalacji oddanych do użytkowania po wejściu $\mathrm{w}$ życie ustawy - 0,35 zł z $1 \mathrm{~m}^{3}$ bezzwrotnie pobranej wody powierzchniowej oraz 0,082 zł za $1 \mathrm{~m}^{3}$ wody pobranej zwrotnie. Dla istniejących podmiotów opłata za pobór zwrotny nie będzie naliczana.

Aby dokonać oceny wpływu ustanowienia opłat w energetyce na cenę energii elektrycznej, oszacowano przeciętne zużycie wody (zwrotne i bezzwrotne) dla potrzeb produkcji energii elektrycznej na podstawie danych GUS. Dane wyjściowe dla sektora energetyki (dział 35.1 według Polskiej Klasyfikacji Działalności):

pobór zwrotny dla celów chłodzenia ${ }^{39}-6465 \mathrm{hm}^{3}$

pobór bezzwrotny dla celów chłodzenia ${ }^{40}-178 \mathrm{hm}^{3}$

pobór maksymalny $=200 \% \cdot 6643 \mathrm{hm}^{3} / \mathrm{rok}=420 \mathrm{~m}^{3} / \mathrm{s}$

produkcja energii elektrycznej w elektrowniach cieplnych ${ }^{41}-148 \mathrm{TWh}$

średni pobór zwrotny na produkcję $1 \mathrm{MWh}$ energii elektrycznej $-43,7 \mathrm{~m}^{3} / \mathrm{MWh}$ średni pobór bezzwrotny na $1 \mathrm{MWh}$ energii elektrycznej - 1,2 $\mathrm{m}^{3} / \mathrm{MWh}$ stawka opłaty stałej $=1000 \mathrm{zł}$ na dobę za $1 \mathrm{~m}^{3} / \mathrm{s}$ wody powierzchniowej stawka opłaty zm. pobór bezzwrotny $=0,35 \mathrm{zł} z a 1 \mathrm{~m}^{3}$ wody powierzchniowej stawka opłaty zm. pobór zwrotny $=0,082$ zł za $1 \mathrm{~m}^{3}$ wody powierzchniowej

39 Ilość wód chłodniczych odprowadzonych w 2014 r. według rocznika: Ochrona Środowiska 2015, GUS, Warszawa 2015, tabl. 37(84).

${ }^{40}$ Obliczone jako: wielkość poboru z ujęć własnych pomniejszona o zrzut wód chłodniczych, sprzedaż wody i zakup wody z wodociągów, dane za 2014 r., Ochrona Środowiska..., tabl. 19(66).

${ }^{41}$ Bank Danych Lokalnych GUS, dane w Kategorii: Rynek materiałowy i paliwow-energetyczny. 
/MWh

Opłata $\mathrm{zm} .=1,2 \frac{\mathrm{m}^{3}}{\mathrm{MWh}} \cdot 0,35 \frac{\mathrm{zł}}{\mathrm{m}^{3}}+43,7 \frac{\mathrm{m}^{3}}{\mathrm{MWh}} \cdot 0,082 \frac{\mathrm{zł}}{\mathrm{m}^{3}}=4,00 \mathrm{zł} / \mathrm{MWh}$

Opłata stała + zmienna $=5,00 \mathrm{zł} / \mathrm{MWh}$

Opłata za pobór wody będzie na poziomie 5\% ceny energii 169,99zł/MWh ${ }^{42}$. Tego rzędu dodatkowy koszt nie wpłynie więc znacząco na cenę energii.

W przypadku energetyki wodnej proponowane rozwiązania dotyczące opłat są korzystniejsze, elektrownie wodne nie będą ponosić opłaty stałej, a jedynie opłatę zmienną. Stawka opłaty została określona na poziomie 1,24 zł za $1 \mathrm{MWh}$ wyprodukowanej energii elektrycznej w obiekcie energetyki wodnej za zwrotny pobór wody.

\section{Opłaty za odprowadzanie wód opadowych oraz utratę naturalnej retencji}

Przykładowa kalkulacja opłaty stałej dla obszaru osiedla mieszkaniowego częściowo uszczelnionego o powierzchni 20 ha, z którego odprowadzany jest według pozwolenia maksymalny zrzut wód opadowych w wysokości 500 1/s została przeprowadzona we wcześniejszym podrozdziale. Opłata stała za cały rok została oszacowana na poziomie 46 tys. zł. Opłata zmienna będzie zależeć od rzeczywistego zrzutu, który będzie oczywiście zależny od opadów w danym roku. W Krakowie średnia roczna suma opadów atmosferycznych wynosi ok. $700 \mathrm{~mm}^{43}$ (średnie sumy z lat 2001-2005: $686 \mathrm{~mm}$, z lat 2001-2010 $720 \mathrm{~mm}$, suma opadów w $2010 \mathrm{r}$.: $1020 \mathrm{~mm}$, w 2014 r.: $626 \mathrm{~mm}$ ). Opłata zmienna wynikająca z tych danych:

powierzchnia $=20 \mathrm{ha}$, współczynnik spływu $=0,5^{44}$

opad roczny $626 \mathrm{~mm}$ : opłata $\mathrm{zm} .=626 \mathrm{~mm} \cdot 20 \mathrm{ha} \cdot 0,5 \cdot 1,50 \frac{\mathrm{zł}}{\mathrm{m}^{3}}=94$ tys. $\mathrm{zł}$ opad roczny $720 \mathrm{~mm}$ : opłata zm. $=108$ tys. zł

opad roczny $1020 \mathrm{~mm}$ : opłata zm. $=153$ tys. zł

Łączna opłata (stała plus zmienna) waha się od 150 do 200 tys. zł w skali roku. Przeliczając opłatę na mieszkańca, jest to od 50 do $70 \mathrm{zł}$, czyli ok. 200-300 zł na gospodarstwo domowe na rok. Wydatki na wodę wodociągową

${ }^{42}$ Informacja Prezesa Urzędu Regulacji Energetyki nr 13/2016 w sprawie średniej ceny sprzedaży energii elektrycznej na rynku konkurencyjnym za rok 2015, http://ure.gov.pl/pl/rynki-energii/ energia-elektryczna/srednie-ceny-energii-i (dostęp: 1.06.2016).

${ }^{43}$ Rocznik statystyczny Krakowa 2015, US w Krakowie, Kraków 2015, s. 72.

${ }^{44}$ Współczynnik spływu/szczelności zlewni to stosunek wielkości spływu z danej powierzchni do ilości opadu, która spadła na tę powierzchnię, dla przykładowych rodzajów powierzchni: drogi bitumiczne $0,85-0,90$; bruki kamienne $0,70-0,85$; zabudowa zwarta $0,50-0,70$; zabudowa luźna 0,30-0,50, R. Edel, Odwodnienie dróg, Wydawnictwo Komunikacji i Łączności, Warszawa 2000, s. 40 . 
można oszacować na poziomie ok. 140 zł/rok (zużycie wody $32 \mathrm{~m} 3 /$ os./rok, cena 3,62 zł netto/m³ + VAT). Przy wzroście opłat za wodę do 4,19 zł netto/m³ + VAT opłaty za wodę wzrosną do $165 \mathrm{zł} /$ rok, obciążenie z tytułu opłat za ścieki nie powinno ulec znaczącym zmianom (stawki opłat zmiennych nie są podnoszone) i wynosi ok. 205 zł/rok (ilość ścieków 33 m³/os./rok, cena 5,22 zł netto/m $/ \mathrm{m}^{3}$ + VAT). Dodatkowa opłata związana z gospodarowaniem wodami opadowymi (60 zł) daje łączne wydatki na poziomie ok. $430 \mathrm{zł} /$ rok, czyli 36 zł/mies. (dotychczas ok. 29 zł/mies.). W celu oceny poziomu cen odnosi się wysokość opłat do tzw. przeciętnego miesięcznego dochodu rozporządzalnego, który według GUS w 2015 r. wyniósł 1386 zł na 1 osobę. Dotychczasowe opłaty za wodę i ścieki stanowiły ok. 2,1\% dochodu rozporządzalnego, teraz poziom opłat spowoduje przyrost tego wskaźnika do 2,6\%, co wydaje się znaczącym zbliżeniem się do wartości progowej 3\%, który często też jest podawany jako próg akceptowalności społecznej $^{45}$.

Opłata zmienna może być zmniejszona przy zastosowaniu urządzeń retencjonujących wody opadowe o pojemności powyżej $20 \%$ odpływu rocznego z powierzchni szczelnych, stawka maleje $0,75 \mathrm{zł}$ za $1 \mathrm{~m}^{3}$ na 1 rok, a z urządzeniami o pojemności powyżej 30\% odpływu rocznego do 0,15 zł za $1 \mathrm{~m}^{3}$ na 1 rok.

W takim przypadku opłaty wyniosłyby dziesięciokrotnie mniej, odpowiednio:

opad roczny $626 \mathrm{~mm}$ : opłata $\mathrm{zm} .=626 \mathrm{~mm} \cdot 20$ ha $\cdot 0,5 \cdot 0,15 \frac{\mathrm{zł}}{\mathrm{m}^{3}}=9$ tys. zł opad roczny $720 \mathrm{~mm}$ : opłata $\mathrm{zm} .=11$ tys. zł

opad roczny $1020 \mathrm{~mm}$ : opłata $\mathrm{zm} .=15$ tys. zł

Podobne rozwiązania promujące retencjonowanie wód opadowych zastosowano przy konstrukcji opłaty za utratę naturalnej retencji. Jest to opłata analogiczna do powyższej za odprowadzanie wód opadowych do systemów kanalizacyjnych, ale jest stosowana na terenach nieobjętych systemem kanalizacji; opłatą objęte będą obszary szczelne o powierzchni powyżej $1000 \mathrm{~m}^{2}$. W tym przypadku również zastosowanie retencji wód opadowych może obniżyć podstawową stawkę $0,60 \mathrm{zl}$ za $1 \mathrm{~m}^{2}$ do $0,10 \mathrm{zl} / \mathrm{m}^{2}$, jeśli zastosuje się urządzenia do retencjonowania wody o pojemności powyżej 30\% odpływu rocznego z obszarów uszczelnionych.

Wprowadzenie opłat za wody opadowe oraz utratę retencji, które będą ponoszone przez zarządzających obszarami objętymi opłatami (zarządcy osiedli, parkingów itd.) lub właścicieli kanalizacji, zapewne spowoduje wprowadzenie podobnej opłaty od mieszkańców (np. w czynszu za mieszkanie). Takie rozwiązania są już stosowane w wielu miastach w kraju. Na branżowym portalu www. retencja.pl zgromadzono dane z 82 gmin i miast, które stosują opłaty za wody

${ }^{45}$ Metodyka zastosowania kryterium dostępności cenowej w projektach inwestycyjnych z dofinansowaniem UE, Departament Wsparcia Projektów Partnerstwa Publiczno-Prywatnego, Ministerstwo Infrastruktury i Rozwoju, Warszawa, wrzesień 2015, s. 3. 
opadowe ${ }^{46}$. Stosowane są rozwiązania uzależniające opłatę zarówno od powierzchni, jak i od objętości odprowadzanej wody ${ }^{47}$. Projekt ustawy spowoduje, że opłaty za wody opadowe staną się powszechne, co przy dosyć wysokich stawkach i możliwości ich obniżenia przez retencję przyczyni się zapewne do lepszego gospodarowania wodami opadowymi w miastach.

\section{Podsumowanie}

Opracowany projekt prawa wodnego wprowadza szereg nowych instrumentów ekonomicznych wspomagających racjonalną gospodarkę zasobami wodnymi. Likwidacja funkcjonujących obecnie zwolnień z opłat przyczyni się do ponoszenia przez wszystkich korzystających z zasobów wodnych kosztów kształtowania i ochrony tych zasobów, a więc przyczyni się do stosowania zasady zwrotu kosztów usług wodnych. Opłaty stałe doprowadzą zapewne do weryfikacji i urealnienia pozwoleń wodnoprawnych. Likwidacja zwolnień i znaczne podniesienie stawek opłat jednostkowych może spowodować znaczący wzrost kosztów funkcjonowania podmiotów objętych opłatami, co jednak niekoniecznie musi znacząco przełożyć się na ceny produktów - jak zostało to pokazane na przykładzie opłat w sektorze produkcji energii elektrycznej oraz produkcji wód i napojów. Jednakże wykazano również, że opłaty za usługi wodne mogą znacząco podnieść cenę wody wodociągowej, dodatkowo gospodarstwa domowe zapewne zostaną obciążone nowymi opłatami będącymi pochodnymi opłat za odprowadzanie wód opadowych oraz utratę naturalnej retencji.

\section{Bibliografia}

Burszta-Adamiak E., Mechanizmy finansowe gospodarowania wodami opadowymi $w$ miastach, „Zrównoważony Rozwój - Zastosowania” 2014, nr 5 („Woda w Mieście”).

Edel R., Odwodnienie dróg, Wydawnictwo Komunikacji i Łączności, Warszawa 2000.

Informacja Prezesa Urzędu Regulacji Energetyki nr 13/2016 w sprawie średniej ceny sprzedaży energii elektrycznej na rynku konkurencyjnym za rok 2015, http://ure.gov.pl/pl/rynki-energii/ energia-elektryczna/srednie-ceny-energii-i (dostęp: 1.06.2016).

Metodyka zastosowania kryterium dostępności cenowej w projektach inwestycyjnych z dofinansowaniem UE, Departament Wsparcia Projektów Partnerstwa Publiczno-Prywatnego, Ministerstwo Infrastruktury i Rozwoju, Warszawa, wrzesien 2015, https://www.funduszeeuropejskie. gov.pl/media/8776/metodyka_dostepnosci_cenowej.pdf (dostęp: 1.06.2016).

Ochrona środowiska 2015. Informacje i opracowania statystyczne, GUS, Warszawa 2015.

${ }^{46} \mathrm{http}: / /$ retencja.pl/deszcz/oplaty-za-wody-opadowe-i-roztopowe/ (dostęp: 1.06.2016).

${ }^{47}$ Burszta-Adamiak E., Mechanizmy finansowe gospodarowania wodami opadowymi w miastach, „Zrównoważony Rozwój - Zastosowania” 2014, nr 5 („Woda w Mieście”). 
Projekt ustawy Prawo wodne z 23 czerwca 2016 r., Ministerstwo Środowiska, http://legislacja.rcl. gov.pl/projekt/12284651/katalog/12349263 (dostęp: 1.06.2016).

Rachunek zysków i strat za rok 2015, http://bip.mpwik.krakow.pl/katalog/strona,15.html (dostęp: 1.06.2016).

Rocznik statystyczny Krakowa 2015, US w Krakowie, Kraków 2015.

Rozporządzenie Nr 4/2014 Dyrektora Regionalnego Zarządu Gospodarki Wodnej w Krakowie z dnia 16 stycznia 2014 r. w sprawie warunków korzystania z wód regionu wodnego Górnej Wisły. Załącznik nr 5. Wykaz czynnych posterunków wodowskazowych wraz z ich charakterystyką hydrologiczną.

Rozporządzenie Rady Ministrów z dn. 12 października 2015 r. w sprawie opłat za korzystanie ze środowiska (Dz.U. 2015 r., poz. 1875).

Ustawa z dn. 27 kwietnia 2001 r. Prawo ochrony środowiska (Dz.U. 2016, poz. 672 z późn. zm.).

http://legislacja.rcl.gov.pl/projekt/12284651/katalog/12349263 (dostęp: 1.06.2016).

http://retencja.pl/deszcz/oplaty-za-wody-opadowe-i-roztopowe/ (dostęp: 1.06.2016).

http://wodociagi.krakow.pl/o-firmie/infrastruktura.html (dostęp: 1.06.2016).

\section{Streszczenie}

W tekście przedstawiono planowane zmiany w systemie opłat środowiskowych wynikających z rządowego projektu ustawy wodnej z dnia 23 czerwca 2016 r. Porównanie istniejących i proponowanych instrumentów ekonomicznych jest wykonane na podstawie przepisów projektowanej ustawy oraz przepisów obowiązujących. Zostały przeprowadzone analizy stawek opłat za usługi wodne oraz wpływu ich zmian na ceny niektórych produktów i usług.

Słowa kluczowe: opłaty ekologiczne, zasoby wodne, prawo wodne 